\title{
Metal ions, Alzheimer's disease and chelation therapy
}

ANA BUDIMIR

University of Zagreb

Faculty of Pharmacy and Biochemistry 10000 Zagreb, Croatia

Accepted January 27, 2011
In the last few years, various studies have been providing evidence that metal ions are critically involved in the pathogenesis of major neurological diseases (Alzheimer, Parkinson). Metal ion chelators have been suggested as potential therapies for diseases involving metal ion imbalance. Neurodegeneration is an excellent target for exploiting the metal chelator approach to therapeutics. In contrast to the direct chelation approach in metal ion overload disorders, in neurodegeneration the goal seems to be a better and subtle modulation of metal ion homeostasis, aimed at restoring ionic balance. Thus, moderate chelators able to coordinate deleterious metals without disturbing metal homeostasis are needed. To date, several chelating agents have been investigated for their potential to treat neurodegeneration, and a series of 8-hydroxyquinoline analogues showed the greatest potential for the treatment of neurodegenerative diseases.

Keywords: metal ions, Alzheimer's disease, neurodegeneration, metal chelators, chelation therapy

Alzheimer's disease (AD) is a progressive and fatal neurodegenerative disease, clinically characterized by memory and cognitive dysfunctions. It is primarily a disease of old age (1) and is the most prevalent cause of dementia in elderly people (2). AD affects about 35 million people worldwide today (3) and it is estimated to nearly double every 20 years, to reach 66 million in 2030, and 115 million in 2050 (3). There is no known cause and no cure for $\mathrm{AD}$ and these numbers makes finding a cure or rational treatment for $\mathrm{AD}$ an urgent priority. Despite significant advances in understanding the neuropathological and neurochemical events taking place in AD, the etiopathogenesis of progressive and mental cognitive dysfunction associated with aging remains largely unclear.

Pathologically, AD is characterized by neuronal degeneration. The brains of AD patients are mainly characterized by extracellular proteic (or neuritic) deposits (amyloid or senile plaques) surrounded by dystrophic neuritic and intracellular neurofibrillary tangles (NFT) (4). The plaques and tangles are present mainly in brain regions involved in learning and memory and emotional behavior such as the entorhinal cortex, hippocam-

*Correspondence; e-mail: anab@pharma.hr 
pus, basal forebrain and amygdale. Brain regions with plaques typically exhibit reduced numbers of synapses, and neurites associated with the plaques are often damaged. Neurons that use glutamate or acetylcholine as neurotransmitters appear to be particularly affected, but neurons that produce serotonin and norepinephrine are also damaged.

\section{Neurofibrillary tangles}

Neurofibrillary tangles are intracellular fibrillar aggregates of the microtubule-associated proteins Tau, which exhibit hyperphosphorylation and severe oxidative modifications. Native Tau proteins possess between 352 and 441 amino acids (molecular weight 55 to $62 \mathrm{kDa}$ ). These Tau proteins are microtubule-associated proteins abundant in neurons. They interact with tubulin to stabilize microtubules and to promote tubulin assembly into microtubules. Hyperphosphorylation of Tau proteins at abnormal sites (serine and threonine residues) can result in the self-assembly of tangles of paired helical filaments and straight filaments $(5,6)$ in neurons undergoing degeneration, which are involved in the pathogenesis of AD and other tauopathies. It has also been proposed that $\mathrm{Al}(\mathrm{III})$ and $\mathrm{Fe}$ (III) cations, found within the neurofibrillary tangles, could be partially involved in the polymerization processes of hyperphosphorylated Tau proteins (7-9).

\section{Amyloid peptides}

Extracellular proteic plaques are built up by fibrils (10), whose major components are peptides known as $\beta$-amyloid (A $\beta)$, which range in length from 39 to 43 amino acids. These amyloid peptides originate from sequential proteolytic cleavages $(11,12)$ of a common precursor called Amyloid Precursor Protein (APP) (13). APP is a large glycoprotein of 695 to 770 amino acids that comprises three parts, the extracellular N-terminal region, a single hydrophobic transmembrane region and the cytoplasmic C-terminal domain. Overexpression of APP could lead to early AD forms (14). The amino acid sequence of the largest amyloid peptide $A \beta-(1-42)$ is given in Fig. 1 (15).

\footnotetext{
${ }^{+} \mathrm{H}_{3} \mathrm{~N}-\mathrm{Asp}^{1}$-Ala-Glu-Phe-Arg-His ${ }^{6}$-Asp-Ser ${ }^{8}-\mathrm{Gly}-\mathrm{Tyr}^{10}$-Glu-Val-His ${ }^{13}-\mathrm{His}^{14}$-GIn-Lys-LeuVal-Phe-Phe-Ala-Glu-Asp-Val-Gly ${ }^{25}$-Ser-Asn-Lys ${ }^{28}$-Gly-Ala-Ile-Ile-Gly-Leu-Met ${ }^{35}$-ValGly-Gly ${ }^{38}-\mathrm{Val}^{-} \mathrm{Val}^{40}-\mathrm{Ile}^{41}-\mathrm{Ala}^{42}-\mathrm{COO}$
}

Fig. 1. Primary structure of $A \beta-(1-42)$. Hydrophobic membrane-derived portion shown in bold. Ile-Ale - lost amino acid residue for $A \beta-(1-42)$ to $A \beta-(1-40)$. Hypothetical amino acids involved in the binding of metal ions.

$\beta$-amyloid peptides have a tendency to aggregate in aqueous solution. Two major forms identified in the amyloid deposits in $A D$ brain are $A \beta-(1-40)$ and $A \beta-(1-42)(16)$. The $A \beta-(1-40)$ isoform is the predominant soluble species in biological fluids $(\approx 90 \%)$, while the less abundant in biological fluids but the predominant species found in plaque deposits $A \beta-(1-42)$ has the highest propensity for aggregation and fibrillogenesis (17). The relative abundance of $A \beta-(1-42)$ with respect to $A \beta-(1-40)$ reflects the fact that even a small elongation (Ile-Ala) of the stretch of hydrophobic residues in the C-terminal region dramatically increases the tendency of this peptide to aggregate (18). The $\beta$-amyloid fibril formation is a rather complex process, which is not yet unraveled (Fig. 2). Im- 
portantly, it is now accepted that $\mathrm{A} \beta$ peptides are neurotoxic in micromolar concentrations depending on their conformational states (19). Some studies have indeed proven that oligomers are 10 times more toxic than fibrils, and 40 times than monomers. Other studies have shown that the soluble oligomeric forms of $A \beta$ are the most toxic species, rather than the more aggregated fibrils or protofibrils (20).

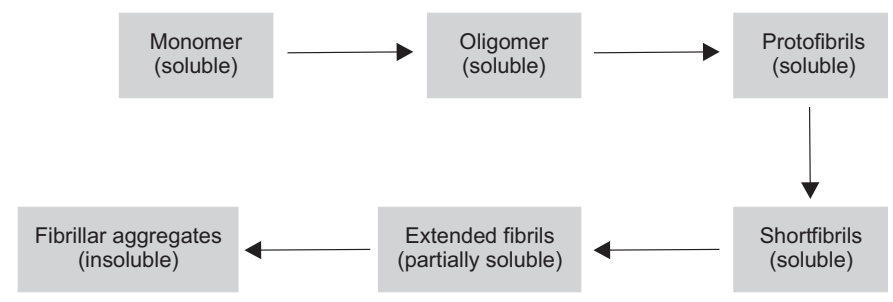

Fig. 2. Postulated $\beta$-amyloid fibril assembly.

To explain the occurrence of amyloid deposits and of neurofibrillary tangles, two hypotheses were proposed: (i) Amyloid cascade hypothesis: Neurodegeneration in AD begins with abnormal processing of the amyloid precursor protein APP and results in the production, aggregation and deposition of the amyloid $\beta$ peptides. The amyloid cascade may facilitate neurofibrillary tangle formation and cell death. (ii) Neuronal cytoskeletal degeneration hypothesis: Cytoskeletal changes are the main events that lead to neurodegeneration in $\mathrm{AD}$, as the hyperphosphorylation and aggregation of Tau proteins are related to the activation of cell death processes.

\section{METAL HOMEOSTASIS IN ALZHEIMER'S DISEASE}

The brain is a specialized organ that requires metal ions for a number of important cellular processes. As such, the brain contains a relatively high concentration of a number of transition metals such as $\mathrm{Fe}, \mathrm{Zn}$, and $\mathrm{Cu}$ where they take part in the neuronal activity within the synapses ( $\mathrm{Zn}{ }^{\mathrm{II}}$ in particular) and ensure the function of various metalloproteins (cytochrome $\mathrm{C}$-oxidase, $\mathrm{Cu} / \mathrm{Zn}$ superoxyde dismutase...). Cells have therefore developed a sophisticated machinery for controlling metal-ion homeostasis. However, a breakdown of these mechanisms, or absorption of metals with no known biological function, alter the ionic balance and can result in a disease state, including several neurodegenerative disorders such as $\mathrm{AD}$ (21). Understanding the complex structural and functional interactions of metal ions with the various intracellular and extracellular components of the central nervous system, under normal conditions and during neurodegeneration, is essential for the development of effective therapies.

Many studies have shown that the most important biometals, i.e., copper, zinc, and iron as well as nonphysiological aluminium are involved in AD. They are suggested to have two distinct roles in the pathophysiology of AD: (i) aggregation of A $\beta$ peptide, and (ii) production of reactive oxygen species induced by $\mathrm{A} \beta$. 


\section{Copper}

A significant amount of literature has accrued on examining the role of copper in the pathogenesis of $\mathrm{AD}$ (for recent review see ref. 22). One of the key findings emerging from these studies is that there is an excess of copper in the extracellular space of the brain (23). Studies by Lovell et al. (24) demonstrated high concentration of $\mathrm{Cu}$ in amyloid plaques $(\sim 400 \mu \mathrm{M})$ compared to the normal brain extracellular concentration of $0.2-1.7 \mu \mathrm{mol} \mathrm{L}-1$. This accumulation of extracellular copper is likely to be mediated by copper binding to the $A \beta$ peptide. Aggregation of $A \beta$ peptides is a central phenomenon in AD. Although A $\beta$ peptides undergo spontaneous self-aggregation, it is clear from experiments in vitro that $\mathrm{Cu}^{2+}$ affects aggregation behavior of $\mathrm{A} \beta$. The $\mathrm{Cu}$-induced $\mathrm{A} \beta$ aggregation is still controversial, as accelerating and inhibiting effects have been published, which apparently depend on the experimental conditions such as $\mathrm{pH}$, salt and metal concentrations $(25,26)$. It is suggested that, on one hand, $\mathrm{Cu}$ promotes amorphous aggregates and, on the other, $\mathrm{Cu}$ reduces formation of fibrils (27). In addition, $\mathrm{Cu}$ binding to $\mathrm{A} \beta$ can result in production of hydrogen peroxide through reduction of $\mathrm{Cu}(\mathrm{II})$ to $\mathrm{Cu}(\mathrm{I})$ and subsequent generation of a highly toxic hydroxyl radical through the Fenton reaction. Consequently, a cascade of events related to oxidative stress and subsequent neuronal death occurs (28).

In contrast to increased extracellular $\mathrm{Cu}$ levels, intracellular $\mathrm{Cu}$ levels appear to be reduced in AD brain compared to controls (29). Moreover, the activity of several cuproenzymes is diminished in AD, including copper/zinc superoxide (30) and cytochrome c oxidase (31). Additionally, interactions of copper with Tau peptide have been assumed to induce the development of neurofibrillary tangles, one of the hallmarks of AD (32).

\section{Zinc}

The potential role of zinc in the pathology of AD (for recent review see ref. 33) was emphasized by the finding of $\mathrm{Zn}$ enrichment within AD plaques and a $\mathrm{Zn}$ increase in the neuropil of AD patients compared to controls (24). Zinc has a crucial role in A $\beta$ aggregation, which is the most well-established contribution that zinc may have in AD pathogenesis. Aggregation of A $\beta$ peptides into protease-resistant deposits can be rapidly induced in the presence of zinc ions under physiological conditions in vitro $(34,35)$. $\mathrm{Zn}$ binds to $A \beta$ in a monomeric and stoichiometric $\mathrm{Zn}-\mathrm{A} \beta$ complex, which is transiently stable prior to aggregation; the structure of the aggregates was described to be more amorphous, i.e., to contain less fibril (36). This activity may not be that of a neurotoxic modulator but rather of a neuroprotective agent since $\mathrm{Zn}$ can alleviate $\mathrm{A} \beta$ toxicity in cortical cultures (37). The precise mechanism of the protective effect of zinc against $A \beta$ toxicity is unclear; nevertheless, the possible mechanism may include competing with $\mathrm{Cu}$ (or iron) for $A \beta$ binding. Binding of zinc to $A \beta$ changes its conformation to the extent that copper ions cannot reach its metal binding sites. Preventing copper from interacting with $A \beta$ may prevent the $\mathrm{Cu}-\mathrm{A} \beta$ induced formation of hydrogen peroxide and free radicals.

Recently, it has been shown that zinc can also accelerate the aggregation of a Tau peptide, the major protein subunit of neurofibrillary tangles, under reducing conditions (38). Zinc inhibited the formation of intramolecular disulphide bonds but promoted intermolecular bonds between key cysteine residues. 
Iron

Iron is a redox active metal, and its contributions to AD pathology are still unclear. Within AD plaques, iron accumulates to almost 3 times that of normal neuropil levels $\left(\sim 1 \mathrm{mmol} \mathrm{L}{ }^{-1}\right.$ compared to $\sim 350 \mu \mathrm{mol} \mathrm{L}^{-1}$ in a healthy control neuropil) (24). Despite having a high concentration in AD plaques, Fe ions are not likely to interact directly with $A \beta$ in vivo. Although in vitro studies indicate that Fe induces $A \beta$ aggregation (39), Fe does not copurify with $\mathrm{A} \beta$ extracted from plaques (40), unlike $\mathrm{Cu}$ and $\mathrm{Zn}$ ions, and is found primarily complexed with ferritin in the plaque-associated neuritic processes.

Oxidative stress is one of the earliest events in AD and seems to be involved in the onset, progression and pathogenesis of the disease (41). A variety of studies have demonstrated that iron plays a pivotal role in the oxidative damage observed in proteins, lipids, sugars, and nucleic acid. Like $\mathrm{Cu}$, Fe has been associated with free radical generation through the Fenton reaction, leading to the formation of a highly reactive hydroxyl radical.

In addition, Fe was found to accumulate in neurons with neurofibrillary tangles (42). $\mathrm{Fe}^{3+}$ has the ability to bind with hyperphosphorylated Tau and to induce its aggregation in vitro, leading to the formation of neurofibrillary tangles in AD. This process can be reversed by reduction of $\mathrm{Fe}^{3+}$ back to $\mathrm{Fe}^{2+}(8)$.

\section{Aluminium}

Aluminium is the most widely distributed metal in the environment and is widely used in daily life, thus providing easy exposure to human beings. Al was first suspected to be implicated in the progression of $\mathrm{AD}$, when it was observed that intra-cerebral injection of this element into rabbits induced the formation of neurofibrillary tangles (43, 44). $\mathrm{Al}(\mathrm{III})$ is known to localize at high concentrations in AD amyloid deposits, but studies aimed at determining if it is elevated in AD brains, have not achieved consensus. It was reported that $\mathrm{Al}(\mathrm{III})$ can induce $\mathrm{A} \beta$ aggregation, but the reported metal concentrations have since been claimed to be significantly above physiological levels, and when $\mathrm{A} \beta$ was exposed to lower micromolar levels of aluminium, no $\mathrm{A} \beta$ aggregation was induced (45). Overall, it appears that although this element may be a contributing factor to the neurodegeneration in $\mathrm{AD}$, it does not appear to have a causative role.

Metal coordination properties of $A \beta$ have been investigated employing a wide range of techniques such as nuclear magnetic resonance (NMR) spectroscopy, electron paramagnetic resonance (EPR) spectroscopy, circular dichroism (CD) spectroscopy, and mass spectrometry (MS) (46-48). These studies have suggested that the coordination of $\mathrm{Cu}(\mathrm{II})$ and $\mathrm{Zn}(\mathrm{II})$ in $\mathrm{A} \beta$ species could occur via three histidine residues (H6, H13, and H14) and possibly another $N$-terminal residue or the peptide backbone.

\section{METALS CHELATORS FOR THE TREATMENT OF ALZHEIMER'S DISEASE}

The precise mechanisms responsible for triggering neurodegenerative AD remain unclear and hinder ready identification of therapeutic targets for pharmaceutical development. However, there has been a growing interest in a number of pharmacological ap- 
proaches to help slow down the rate of both cognitive and functional declines associated with aging while maintaining a positive quality of life. One of the currently accepted hypotheses, the metal hypothesis of Alzheimer's disease states that the interactions between metal ions and $A \beta$, as well as abnormal metal ion homeostasis, are connected with $A D$ neuropathogenesis (49-51). Based on this hypothesis, disruption of metal-A $\beta$ interactions via metal chelation therapy has been proposed in order to reduce neurotoxicity of metal-A $\beta$ species and restore metal ion homeostasis in the brain (52). However, in order to be used as potential drugs in the treatment of neurodegenerative diseases, chelators must have particular properties. They must have a low molecular weight, be poorly or not charged to favor the blood brain barrier (BBB) crossing and stable. They must selectively target certain metal ions, because a strong non-specific chelation would result in a general depletion of metal ions, including those of metalloenzymes, which are essential. Once the chelator is in the brain, the molecule must be able to complex the metal ions present in excess in the aggregated proteins so as to allow their dissolution and elimination. Finally, successful treatment with any chelator requires low toxicity and minimum side effects of the drug itself.

To date, several metal chelators have been used as agents for metal ion chelation therapy in AD. Desferrioxamine B (Desferal ${ }^{\circledR}$, Fig. 3) was the first compound used to treat metal overload in the CNS and to dissolve amyloid aggregates. The use of this compound significantly reduced the behavioral and cognitive declines of AD patients (53). However, the use of this siderophore also led to various disadvantages: (i) its hydrophilic and charged character disables the BBB crossing (ii) it is rapidly degraded in vivo, and (iii) it causes significant side effects (anemia...) because of its strong affinity for Fe(III) and other divalent cations.<smiles>CNC(=O)CCC(=O)N(C)CNC(=O)CCC(=O)N(C)O</smiles>

Fig. 3. Chemical structure of desferrioxamine B.

Several other chelating agents (Fig. 4) have been investigated for their potential to treat neurodegeneration (54-59). The lipophilic metal chelator DP-109 significantly reduced amyloid pathology in brains of human amyloid $\beta$ precursor protein transgenic mice (59). Compound XH1, based on a novel "pharmacophore conjugation « concept, is a bifunctional metal chelator containing a DTPA-based binding unit and 4-benzothiazole-2-yl-phenylamine-amyloid binding units. It was shown to specifically reduce APP protein expression in human SH-SY5Y neuroblastoma cells and to attenuate cerebral A $\beta$ amyloid pathology in PS1/APP transgenic mice without inducing apparent toxicity and behavior disturbances (57). Derivatives of a 14-membered saturated tetraamine have also attracted some recent interest. Bicyclam analogue JKL169 (1,1'-xylyl bis-1,4,8,11 tetraazacyclotetradecane) was effective in reducing $\mathrm{Cu}$ levels in the brain cortex and was able to maintain normal $\mathrm{Cu}$ levels in the blood, CSF and corpus callossum in rats (60). 


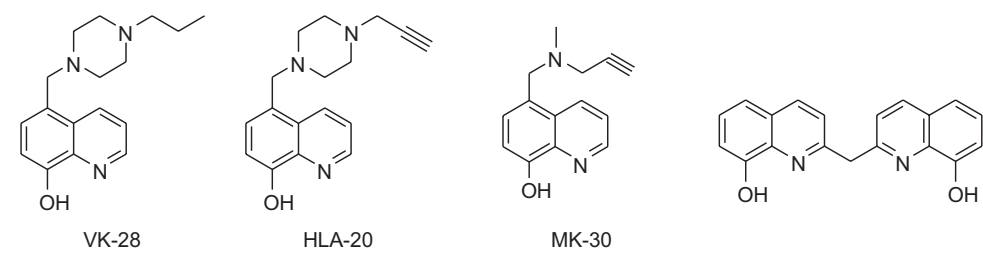

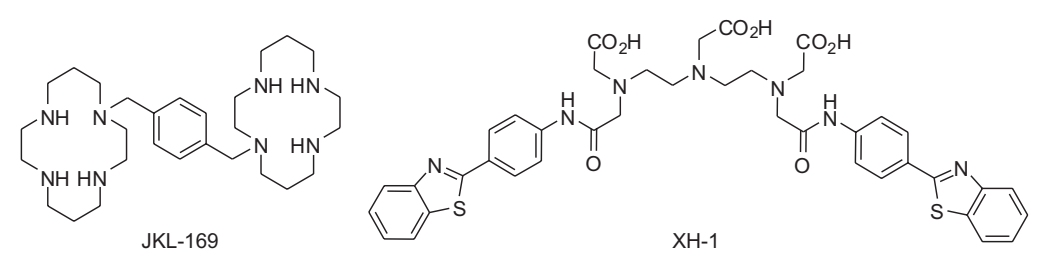

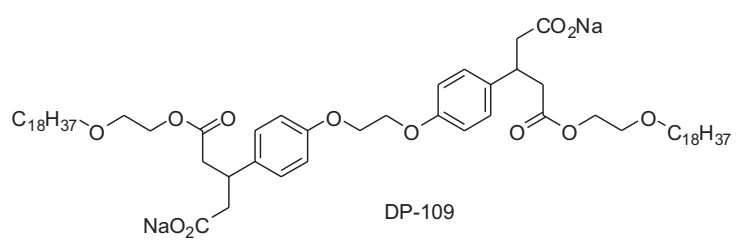

Fig. 4. Chemical structure of chelators tested in AD.

A series of 8-hydroxyquinoline analogues (VK-28, HLA-20 and MA-30) (Fig. 4) have shown the greatest potential for the treatment of several neurodegenerative diseases (61) and one of these compounds, clioquinol (PBT1, Fig. 5), reached the pilot phase II clinical trial (62-66), which suggests that clioquinol improves cognition and lowers plasma levels of $\mathrm{A} \beta 42$ in some patients.

Clioquinol (5-chloro-7-iodo-8-hydroxyquinoline, CQ) is a small, lipophilic and bioavailable metal chelator that has been reported to efficiently cross the BBB (67) and dissolves amyloid plaques of the brain, probably by removing metal ions from the structure (which could allow restoring of their redistribution) $(63,66)$.

Originally, clioquinol was developed by Ciba-Geigy and was widely used as a safe intestinal disinfectant until it was withdrawn from oral use in 1970 (68) after it was associated with an epidemic of neurotoxicity in Japan known as subacute myelo-opticoneuropathy. The mechanism of this toxicity has not been precisely defined. The current leading hypothesis is that clioquinol decreases cobalamin (vitamin $\mathrm{B}_{12}$ ) bioavailability, resulting in a deficiency state and a syndrome similar to subacute combined degeneration (69). However, it was reported that, given safely under the conditions of controlled dosing<smiles>Oc1c(I)cc(Cl)c2cccnc12</smiles>

Fig. 5. Chemical structure of clioquinol, CQ. 
and vitamin supplementation, episodes of subacute myelo-opticoneuropathy may be avoided (63).

$\mathrm{CQ}$ binds $\mathrm{Cu}^{2+}$ and $\mathrm{Zn}^{2+}(2: 1$ ratio) in a square, planar arrangement $(70,71)$ with moderate affinity $\left(\log K_{1}(\mathrm{Cu})=12.5, \log K_{2}(\mathrm{Cu})=10.9, \log K_{1}(\mathrm{Zn})=8.5\right.$ and $\log K_{2}(\mathrm{Zn})$ = 7.6) (72). In 1999, Ashley I. Bush and his co-workers have demonstrated that CQ dissolves synthetic $\mathrm{A} \beta-\mathrm{Cu}^{2+} / \mathrm{Zn}^{2+}$ aggregates and amyloid deposits from post-mortem AD brain (73). Using APP2576 transgenic mice (in vivo model of AD), they have shown that oral treatment with clioquinol markedly inhibited amyloid- $\beta$ deposits ( $49 \%$ decrease) in the absence of any noticeable neurotoxicity. Moreover, the general health and body weight parameters were significantly more stable in the tested animals (62). These findings were recently reproduced by C. Grossi et al. (74). A phase II clinical trial further supports the beneficial use of clioquinol in AD patients. In this trial, clioquinol was well tolerated, significantly reduced cognitive decline, and lowered plasma A $\beta$ levels in clioquinol-treated patients compared to those receiving placebo (66). Conflicting hypotheses currently exist of the possible mode of action of CQ and on its ability to interfere with the brain metal metabolism. Unlike high-affinity chelators, at therapeutic doses clioquinol does not cause excretion of metals. Findings of C. Grossi et al. (74), demonstrating a modest but significant elevation of $\mathrm{Zn}^{2+}$ and $\mathrm{Fe}^{2+/ 3+}$ levels in the neocortex and of $\mathrm{Cu}^{2+}$ levels in the hippocampus of CQ-treated TgCRND8 mice, support the hypothesis of CQ as an ionophore facilitating metal uptake in the brain tissue.

Prana Biotechnology, which developed clioquinol (PBT1), has suspended its development after discovering that the manufacturing process of PBT1 contained certain mutagenic »di-iodo « PBT1 impurities that could not be reduced to an acceptable level. A clioquinol related compound, PBT2 (Prana Biotechnolgy), also an 8-hydroxyquinoline derivative but lacking the iodine atom, has completed the phase IIa trial in AD patients (75). PBT2 prevents production of $A \beta$ oligomers, dissolves the existing $A \beta$ oligomers, and enhances cognitive function in transgenic mice (76).

The exact mechanism of action of CQ and PBT2 is still uncertain, so further studies are necessary to better evaluate the safety and effectiveness of CQ or PBT2 as a possible medical treatment for AD.

\section{CONCLUSIONS AND FUTURE PERSPECTIVES}

The brain requires high metal ion concentrations to carry out its numerous essential functions. However, triggered by unclear mechanisms, the metal ion homeostasis is severely dysregulated in Alzheimer's disease and abnormal levels of $\mathrm{Cu}(\mathrm{II}), \mathrm{Zn}$ (II) and $\mathrm{Fe}(\mathrm{III})$ have been found. Consequently, the brain has a poor capacity to cope with the oxidative stress generated by the redox active $\mathrm{Cu}(\mathrm{II})$ and $\mathrm{Fe}(\mathrm{III})$ ions accumulated in $\mathrm{A} \beta$ aggregates. Faced with these neurological disorders, a number of therapeutic strategies aimed at ameliorating or inhibiting $A \beta$ aggregation and induced ROS generation, including the use of antioxidants and metal chelators, are currently being investigated for their possible application in AD therapy. Among the few chelators tested so far, clioquinol was the first to reach the pilot phase II clinical trial, which demonstrates the applicability of this exogenous metal chelator. Although the use of clioquinol has been suspended 
in AD research, a new and promising oxine based analogue PBT2 is presently under development, which clearly indicates that this strategy will be favored. Clioquinol and other lipophilic and mild chelators based on phenanthrolines or $N$-aroyl- $N$ '-picolinoyl hydrazine binding units have shown a great potential in vitro or in vivo and pave the way to the design and preparation of new drugs for AD therapy. Combining antioxidant activity and binding functionality into a single drug would undoubtedly broaden the chances of success in AD therapy.

\section{REFERENCES}

1. D. M. Skovronsky, V. M.-Y. Lee and J. Q. Trojanowski, Neurodegenerative diseases: New concepts of pathogenesis and their therapeutic implications, Annu. Rev. Pathol. Mech. Dis. 1 (2006) 151-170; DOI: 10.1146/annurev.pathol.1.110304.100113.

2. R. Mayeux, Epidemiology of neurodegeneration, Annu. Rev. Neurosci. 26 (2003) 81-104; DOI: 10.1146/annurev.neuro.26.043002.094919.

3. C. P. Ferri, R. Sousa, E. Albanese, W. S. Ribeiro and M. Honyashiki, World Alzheimer Report 2009 - Executive Summary (Eds. M. Prince and J. Jadeson), Alzheimer's Disease International, London 2009, pp. 1-22; http://www.alz.co.uk/adi/publications.html; access date: January 27, 2011.

4. F. M. LaFerla and S. Oddo, Alzheimer's disease: $\mathrm{A} \beta$, tau and synaptic dysfunction, Trends Mol. Med. 11 (2005) 170-176; DOI: 10.1016/j.molmed.2005.02.009.

5. M. Tolnay and A. Probst, Tau protein pathology in Alzheimer's disease and related disorders, Neuropathol. Appl. Neurobiol. 25 (1999) 171-187; DOI: 10.1046/j.1365-2990.1999.00182.x.

6. C. Ballatore, V. M.-Y. Lee and J. Q. Trojanowski, Tau-mediated neurodegeneration in Alzheimer's disease and related disorders, Nature Rev. Neurosci. 8 (2007) 663-672; DOI: 10.1038/nrn2194.

7. C. W. Scott, A. Fieles, L. A. Sygowski and C. B. Caputo, Aggregation of tau protein by aluminum, Brain Res. 628 (1993) 77-84; DOI: 10.1016/0006-8993(93)90940-O.

8. A. Yamamoto, R.-W. Shin, K. Hasegawa, H. Naiki, H. Sato, F. Yoshimasu and T. Kitamoto, Iron (III) induces aggregation of hyperphosphorylated tau, and its reduction to iron (II) reverses the aggregation: implications in the formation of neurofibrillary tangles of Alzheimer's disease, J. Neurochem. 86 (2003) 1137-1147; DOI: 10.1046/j.1471-4159.2002.01061.x.

9. R.-W. Shin, T. P. A. Kruck, H. Murayama and T. Kitamoto, A novel trivalent cation chelator Feralex dissociates binding of aluminum and iron associated with hyperphosphorylated tau of Alzheimer's disease, Brain Res. 961 (2003) 139-146; DOI: 10.1016/S0006-8993(02)03893-3.

10. T. Lührs, C. Ritter, M. Adrian, D. Riek-Loher, B. Bohrmann, H. Döbeli, D. Schubert and R. Riek, 3D structure of Alzheimer's amyloid- $\beta$ (1-42) fibrils, Proc. Natl Acad. Sci. USA 102 (2005) 17342-17347; DOI: 10.1073/pnas.0506723102.

11. W. P. Esler and M. S. Wolfe, A portrait of Alzheimer secretases - new features and familiar faces, Science 293 (2001) 1449-1454; DOI: 10.1126/science.1064638.

12. M. P. Mattson, Pathways towards and away from Alzheimer's disease, Nature 430 (2004) 631-639; DOI: 10.1038/nature02621.

13. M. Shoji, T. Golde, J. Ghiso, T. Cheung, S. Estus, L. Shaffer, X. Cai, D. McKay, R. Tintner and B. Frangione, Production of the Alzheimer amyloid beta protein by normal proteolytic processing, Science 258 (1992) 126-129; DOI: 10.1126/science.1439760.

14. C. L. Masters, G. Simms, N. A. Weinman, G. Multhaup, B. L. McDonald and K. Beyreuther, Amyloid plaque core protein in Alzheimer disease and Down syndrome, Proc. Natl Acad. Sci. USA 82 (1985 ) 4245-4249; DOI: 10.1073/pnas.82.12.4245. 
15. B. Clippingdale, J. D. Wade and C. J. Barrow, The amyloid- $\beta$ peptide and its role in Alzheimer's disease, J. Peptide Sci. 7 (2001) 227-249; DOI: 10.1002/psc.324.abs.

16. C. Vigo-Pelfrey, D. Lee, P. Keim, I. Lieberburg and D. B. Schenk, Amyloid peptide from human cerebrospinal fluid, J. Neurochem. 61 (1993) 1965-1968; DOI: 10.1111/j.1471-4159.1993.tb09841.x.

17. P. Seubert, C. Vigo-Pelfrey, F. Esch, M. Lee, H. Dovey, D. Davis, S. Sinha, M. Schiossmacher, J. Whaley, C. Swindlehurst, R. McCormack, R. Wolfert, D. Selkoe, I. Lieberburg and D. Schenk, Isolation and quantification of soluble Alzheimer's $\beta$-peptide from biological fluids, Nature 359 (1992) 325-327; DOI: 10.1038/359325a0.

18. J. T. Jarret, E. P. Berger and P. T. Lansbury, The C-terminus of the $\beta$ protein is critical in amyloidogenesis, Ann. NY Acad. Sci. USA 695 (1993) 144-148; DOI: 10.1111/j.1749-6632.1993.tb23043.x.

19. A. Lorenzo and B. A. Yankner, Beta-amyloid neurotoxicity requires fibril formation and is inhibited by congo red, Proc. Natl. Acad. Sci. USA 91 (1994 ) 12243-12247; DOI: 10.1073/pnas.91.25.12243.

20. J. Hardy and D. J. Selkoe, The amyloid hypothesis of Alzheimer's disease: Progress and problems on the road to therapeutics, Science 297 (2002) 353-356; DOI: 10.1126/science.1072994.

21. H. Kozlowski, A. Janicka-Klos, J. Brasun, E. Gaggelli, D. Valensin and G. Valensin, Copper, iron, and zinc ions homeostasis and their role in neurodegenerative disorders (metal uptake, transport, distribution and regulation), Coord. Chem. Rev. 253 (2009) 2665-2685; DOI: 10.1016/j.ccr. 2009.05.011.

22. Y. Hung, A. Bush and R. Cherny, Copper in the brain and Alzheimer's disease, J. Biol. Inorg. Chem. 15 (2010) 61-76; DOI: 10.1007/s00775-009-0600-y.

23. P. J. Crouch, K. J. Barnham, A. I. Bush and A. R. White, Therapeutic Treatments for Alzheimer's disease based on metal bioavailability, Drug News Perspect. 19 (2006) 469-474; DOI: 10.1358/dnp. 2006.19.8.1021492.

24. M. A. Lovell, J. D. Robertson, W. J. Teesdale, J. L. Campbell and W. R. Markesbery, Copper, iron and zinc in Alzheimer's disease senile plaques, J. Neurol. Sci. 158 (1998) 47-52; DOI: 10.1016/ S0022-510X(98)00092-6.

25. C. S. Atwood, R. D. Moir, X. Huang, R. C. Scarpa, N. M. E. Bacarra, D. M. Romano, M. A. Hartshorn, R. E. Tanzi and A. I. Bush, Dramatic aggregation of Alzheimer A $\beta$ by $\mathrm{Cu}(\mathrm{II})$ is induced by conditions representing physiological acidosis, J. Biol. Chem. 273 (1998) 12817-12826; DOI: 10.1074/jbc.273.21.12817.

26. B. Raman, T. Ban, K.-I. Yamaguchi, M. Sakai, T. Kawai, H. Naiki and Y. Goto, Metal ion-dependent effects of clioquinol on the fibril growth of an amyloid $\beta$ peptide, J. Biol. Chem. 280 (2005) 16157-16162; DOI: 10.1074/jbc.M500309200.

27. P. Faller, Copper and zinc binding to amyloid- $\beta$ : Coordination, dynamics, aggregation, reactivity and metal-ion transfer, ChemBioChem 10 (2009) 2837-2845; DOI: 10.1002/cbic.200900321.

28. C. Hureau and P. Faller, A[beta]-mediated ROS production by $\mathrm{Cu}$ ions: Structural insights, mechanisms and relevance to Alzheimer's disease, Biochimie 91 (2009) 1212-1217; DOI: 10.1016/ j.biochi.2009.03.013.

29. M. A. Deibel, W. D. Ehmann and W. R. Markesbery, Copper, iron, and zinc imbalances in severely degenerated brain regions in Alzheimer's disease: possible relation to oxidative stress, J. Neurol. Sci. 143 (1996) 137-142; DOI: 10.1016/S0022-510X(96)00203-1.

30. M. C. Boll, M. Alcaraz-Zubeldia, S. Montes and C. Rios, Free copper, ferroxidase and SOD1 activities, lipid peroxidation and $\mathrm{NO}(\mathrm{x})$ content in the CSF. A different marker profile in four neurodegenerative diseases, Neurochem. Res. 33 (2008) 1717-1723; DOI: 10.1007/s11064-008-9610-3.

31. I. Maurer, S. Zierz and H. J. Moller, A selective defect of cytochrome c oxidase is present in brain of Alzheimer disease patients, Neurobiol. Aging 21 (2000) 455-462; DOI: 10.1016/S0197$-4580(00)$ 00112-3. 
32. Q. Ma, Y. Li, J. Du, H. Liu, K. Kanazawa, T. Nemoto, H. Nakanishi and Y. Zhao, Copper binding properties of a tau peptide associated with Alzheimer's disease studied by CD, NMR, and MALDI-TOF MS, Peptides 27 (2006) 841-849; DOI: 10.1016/j.peptides.2005.09.002.

33. N. T. Watt, I. J. Whitehouse and N. M. Hooper, The role of zinc in Alzheimer's disease, Int. J. Alzheimer's Dis. 2011 (2011) in press; DOI: 10.4061/2011/971021.

34. A. Bush, W. Pettingell, G. Multhaup, M. D. Paradis, J. Vonsattel, J. Gusella, K. Beyreuther, C. Masters and R. Tanzi, Rapid induction of Alzheimer A beta amyloid formation by zinc, Science 265 (1994 ) 1464-1467; DOI: 10.1126/science.8073293.

35. K. H. Lim, Y. K. Kim and Y.-T. Chang, Investigations of the molecular mechanism of metal-induced A $\beta$ (1-40) amyloidogenesis, Biochemistry 46 (2007) 13523-13532; DOI: 10.1021/bi701112z.

36. C. Talmard, L. Guilloreau, Y. Coppel, H. Mazarguil, and P. Faller, Amyloid-beta peptide forms monomeric complexes with $\mathrm{Cu}^{\mathrm{II}}$ and $\mathrm{Zn}^{\mathrm{II}}$ prior to aggregation, ChemBioChem 8 (2007) 163-165; DOI: $10.1002 /$ cbic.200600319.

37. M. P. Cuajungco and K. Y. Faget, Zinc takes the center stage: its paradoxical role in Alzheimer's disease, Brain Res. Rev. 41 (2003) 44-56; DOI: 10.1016/S0165-0173(02)00219-9.

38. Z.-Y. Mo, Y.-Z. Zhu, H.-L. Zhu, J.-B. Fan, J. Chen and Y. Liang, Low micromolar zinc accelerates the fibrillization of human tau via bridging of Cys-291 and Cys-322, J. Biolog. Chem. 284 (2009) 34648-34657; DOI: 10.1074/jbc.M109.058883.

39. P. W. Mantyh, J. R. Ghilardi, S. Rogers, E. DeMaster, C. J. Allen, E. R. Stimson and J. E. Maggio, Aluminum, iron, and zinc ions promote aggregation of physiological concentrations of $\beta$-amyloid peptide, J. Neurochem. 61 (1993) 1171-1174; DOI: 10.1111/j.1471-4159.1993.tb03639.x.

40. C. Opazo, X. Huang, R. A. Cherny, R. D. Moir, A. E. Roher, A. R. White, R. Cappai, C. L. Masters, R. E. Tanzi, N. C. Inestrosa and A. I. Bush, Metalloenzyme-like activity of Alzheimer's disease $\beta$-amyloid, J. Biol. Chem. 277 (2002) 40302-40308; DOI: 10.1074/jbc.M206428200.

41. D. G. Smith, R. Cappai and K. J. Barnham, The redox chemistry of the Alzheimer's disease amyloid beta peptide, Biochim. Biophysi. Acta - Biomembranes 1768 (2007) 1976-1990; DOI: 10.2217/ 14796708.2.4.397.

42. P. F. Good, D. P. Perl, L. M. Bierer and J. Schmeidler, Selective accumulation of aluminum and iron in the neurofibrillary tangles of Alzheimer's disease: A laser microprobe (LAMMA) study, Ann. Neurol. 31 (1992) 286-292; DOI: 10.1002/ana.410310310.

43. I. Klatzo, H. Wisniewski and E. Streicher, Experimental production of neurofibrillary degeneration: 1. Light microscopic observations, J. Neuropathol. Exp. Neurol. 24 (1965) 187-199; DOI: 10.1097/ 00005072-196504000-00002.

44. R. D. Terry and C. Pena, Experimental production of neurofibrillary degeneration: 2. Electron microscopy, phosphatase histochemistry and electron prose analysis, J. Neuropathol. Exp. Neurol. 24 (1965) 200-210; DOI: 10.1097/00005072-196504000-00003.

45. D. Drago, M. Bettella, S. Bolognin, L. Cendron, J. Scancar, R. Milacic, F. Ricchelli, A. Casini, L. Messori, G. Tognon and P. Zatta, Potential pathogenic role of $\beta$-amyloid1-42-aluminum complex in Alzheimer's disease, Int. J. Biochem. Cell Biol. 40 (2008) 731-746; DOI: 10.1016/j.biocel. 2007.10.014.

46. A. Rauk, The chemistry of Alzheimer's disease, Chem. Soc. Rev. 38 (2009) 2698-2715; DOI: 10.1039/ b807980n.

47. L. E. Scott and C. Orvig, Medicinal inorganic chemistry approaches to passivation and removal of aberrant metal ions in disease, Chem. Rev. 109 (2009) 4885-4910; DOI: 10.1021/cr9000176.

48. J. A. Duce and A. I. Bush, Biological metals and Alzheimer's disease: Implications for therapeutics and diagnostics, Prog. Neurobiol. 92 (2010) 1-18; DOI: 10.1016/j.pneurobio.2010.04.003.

49. I. Bush and R. E. Tanzi, Therapeutics for Alzheimer's disease based on the metal hypothesis, Neurotherapeutics 5 (2008) 421-432; DOI: 10.1016/j.nurt.2008.05.001. 
50. A. Gaeta and R. C. Hider, The crucial role of metal ions in neurodegeneration: the basis for a promising therapeutic strategy, Br. J. Pharmacol. 146 (2005) 1041-1059; DOI: 10.1038/sj.bjp.0706416.

51. P. Zatta, D. Drago, S. Bolognin and S. L. Sensi, Alzheimer's disease, metal ions and metal homeostatic therapy, Trends Pharmacol. Sci. 30 (2009) 346-355; DOI: 10.1016/j.tips.2009.05.002.

52. L. R. Perez and K. J. Franz, Minding metals: Tailoring multifunctional chelating agents for neurodegenerative disease, Dalton Trans. 39 (2010) 2177-2187; DOI: 10.1039/b919237a.

53. D. R. C. McLachlan, T. P. A. Kruck, W. Kalow, D. F. Andrews, A. J. Dalton, M. Y. Bell and W. L. Smith, Intramuscular desferrioxamine in patients with Alzheimer's disease, Lancet 337 (1991) 1304-1308; DOI: 10.1016/0140-6736(91)92978-B.

54. R. A. Cherny, J. T. Legg, C. A. McLean, D. P. Fairlie, X. Huang, C. S. Atwood, K. Beyreuther, R. E. Tanzi, C. L. Masters and A. I. Bush, Aqueous dissolution of Alzheimer's disease abeta amyloid deposits by biometal depletion, J. Biol. Chem. 274 (1999) 23223-23228; DOI: 10.1074/jbc.274. 33.23223.

55. R. A. Cherny, K. J. Barnham, T. Lynch, I. Volitakis, Q.-X. Li, C. A. McLean, G. Multhaup, K. Beyreuther, R. E. Tanzi, C. L. Masters and A. I. Bush, Chelation and intercalation: Complementary properties in a compound for the treatment of Alzheimer's disease, J. Struct. Biol. 130 (2000) 209-216; DOI: 10.1006/jsbi.2000.4285.

56. C. Boldron, I. Van der Auwera, C. Deraeve, H. Gornitzka, S. Wera, M. Pitié, F. Van Leuven and B. Meunier, Preparation of cyclo-phen-type ligands: Chelators of metal ions as potential therapeutic agents in the treatment of neurodegenerative diseases, ChemBioChem 6 (2005) 1976-1980; DOI: $10.1002 /$ cbic. 200500220 .

57. A. Dedeoglu, K. Cormier, S. Payton, K. A. Tseitlin, J. N. Kremsky, L. Lai, X. Li, R. D. Moir, R. E. Tanzi, A. I. Bush, N. W. Kowall, J. T. Rogers and X. Huang, Preliminary studies of a novel bifunctional metal chelator targeting Alzheimer's amyloidogenesis, Exp. Gerontol. 39 (2004) 1641-1649; DOI: 10.1016/j.exger.2004.08.016.

58. Z. Cui, P. R. Lockman, C. S. Atwood, C.-H. Hsu, A. Gupte, D. D. Allen and R. J. Mumper, Novel D-penicillamine carrying nanoparticles for metal chelation therapy in Alzheimer's and other CNS diseases, Eur. J. Pharm. Biopharm. 59 (2005) 263-272; DOI: 10.1016/j.ejpb.2004.07.009.

59. J.-Y. Lee, J. E. Friedman, I. Angel, A. Kozak and J.-Y. Koh, The lipophilic metal chelator DP-109 reduces amyloid pathology in brains of human [beta]-amyloid precursor protein transgenic mice, Neurobiol. Aging 25 (2004) 1315-1321; DOI: 10.1016/j.neurobiolaging.2004.01.005.

60. V. Moret, Y. Laras, N. Pietrancosta, C. Garino, G. Quelever, A. Rolland, B. Mallet, J. C. Norreel and J. L. Kraus, 1,1 '-Xylyl bis-1,4,8,11-tetraaza cyclotetradecane: A new potential copper chelator agent for neuroprotection in Alzheimer's disease. Its comparative effects with clioquinol on rat brain copper distribution, Bioorg. Med. Chem. Lett. 16 (2006) 3298-3301; DOI: 10.1016/j. bmcl.2006.03.026.

61. H. Zheng, S. Gal, L. M. Weiner, O. Bar-Am, A. Warshawsky, M. Fridkin and M. B. H. Youdim, Novel multifunctional neuroprotective iron chelator-monoamine oxidase inhibitor drugs for neurodegenerative diseases: in vitro studies on antioxidant activity, prevention of lipid peroxide formation and monoamine oxidase inhibition, J. Neurochem. 95 (2005) 68-78; DOI: 10.1111/j.1471$-4159.2005 .03340 . x$.

62. D. Kaur, F. Yantiri, S. Rajagopalan, J. Kumar, J. Q. Mo, R. Boonplueang, V. Viswanath, R. Jacobs, L. Yang, M. F. Beal, D. DiMonte, I. Volitaskis, L. Ellerby, R. A. Cherny, A. I. Bush and J. K. Andersen, Genetic or pharmacological iron chelation prevents MPTP-induced neurotoxicity in vivo: A novel therapy for Parkinson's disease, Neuron 37 (2003) 899-909; DOI: 10.1016/S0896-6273 (03)00126-0.

63. R. A. Cherny, C. S. Atwood, M. E. Xilinas, D. N. Gray, W. D. Jones, C. A. McLean, K. J. Barnham, I. Volitakis, F. W. Fraser, Y.-S. Kim, X. Huang, L. E. Goldstein, R. D. Moir, J. T. Lim, K. Beyreuther, H. Zheng, R. E. Tanzi, C. L. Masters and A. I. Bush, Treatment with a copper-zinc chelator 
markedly and rapidly inhibits [beta]-amyloid accumulation in Alzheimer's disease transgenic mice, Neuron 30 (2001) 665-676; DOI: 10.1016/S0896-6273(01)00317-8.

64. H. Zheng, M. B. H. Youdim, L. M. Weiner and M. Fridkin, Synthesis and evaluation of peptidic metal chelators for neuroprotection in neurodegenerative diseases, J. Pept. Res. 66 (2005) 190-203; DOI: 10.1111/j.1399-3011.2005.00289.x.

65. C. Deraeve, M. Pitie, H. Mazarguil and B. Meunier, Bis-8-hydroxyquinoline ligands as potential anti-Alzheimer agents, New J. Chem. 31 (2007) 193-195; DOI: 10.1039/b616085a.

66. C. W. Ritchie, A. I. Bush, A. Mackinnon, S. Macfarlane, M. Mastwyk, L. MacGregor, L. Kiers, R. Cherny, Q.-X. Li, A. Tammer, D. Carrington, C. Mavros, I. Volitakis, M. Xilinas, D. Ames, S. Davis, K. Beyreuther, R. E. Tanzi and C. L. Masters, Metal-protein attenuation with iodochlorhydroxyquin (clioquinol) targeting $\mathrm{A} \beta$ amyloid deposition and toxicity in Alzheimer disease: $\mathrm{A}$ pilot phase 2 clinical trial, Arch. Neurol. 60 (2003) 1685-1691; DOI: 10.1001/archneur.60.12.1685.

67. A. I. Bush, Metal complexing agents as therapies for Alzheimer's disease, Neurobiol. Aging 23 (2002) 1031-1038. DOI: 10.1016/S0197-4580(02)00120-3.

68. J. Tateishi, Subacute myelo-optico-neuropathy: Clioquinol intoxication in humans and animals, Neuropathology 20 (Suppl.) S20-S24; DOI: 10.1046/j.1440-1789.2000.00296.x.

69. M. S. Yassin, J. Ekblom, M. Xilinas, C. G. Gottfries and L. Oreland, Changes in uptake of vitamin B-12 and trace metals in brains of mice treated with clioquinol, J. Neurol. Sci 173 (2000) 40-44; DOI: 10.1016/S0022-510X(99)00297-X.

70. M. Di Vaira, C. Bazzicalupi, P. Orioli, L. Messori, B. Bruni and P. Zatta, Clioquinol, a drug for Alzheimer's disease specifically interfering with brain metal metabolism: Structural characterization of its zinc(II) and copper(II) complexes, Inorg. Chem. 43 (2004) 3795-3797; DOI: 10.1021/ ic0494051.

71. C. C. Wagner, S. Calvo, M. H. Torre and E. J. Baran, Vibrational spectra of clioquinol and its Cu(II) complex, J. Raman Spectrosc. 38 (2007) 373-376; DOI: 10.1002/jrs.1654.

72. A. Budimir, N. Humbert, M. Elhabiri, I. Osinska, M. Birus and A.-M. Albrecht-Gary, Hydroxyquinoline based binders: Promising ligands for chelatotherapy?, J. Inorg. Biochem, in press; DOI: 10.1016/j.jinorgbio.2010.08.014.

73. R. A. Cherny, J. T. Legg, C. A. McLean, D. P. Fairlie, X. Huang, C. S. Atwood, K. Beyreuther, R. E. Tanzi, C. L. Masters and A. I. Bush, Aqueous dissolution of Alzheimer's disease A $\beta$ amyloid deposits by biometal depletion, J. Biol. Chem. 274 (1999) 23223-23228; DOI: 10.1074/jbc.274.33. 23223.

74. C. Grossi, S. Francese, A. Casini, M. C. Rosi, I. Luccarini, A. Fiorentini, C. Gabbiani, L. Messori, G. Moneti and F. Casamenti, Clioquinol decreases amyloid- $\beta$ burden and reduces working memory impairment in a transgenic mouse model of Alzheimer's disease, J. Alzheimer's Dis. 17 (2009) 423-440.

75. L. Lannfelt, K. Blennow, H. Zetterberg, S. Batsman, D. Ames, J. Harrison, C. L. Masters, S. Targum, A. I. Bush, R. Murdoch, J. Wilson and C. W. Ritchie, Safety, efficacy, and biomarker findings of PBT2 in targeting A $\beta$ as a modifying therapy for Alzheimer's disease: a phase IIa, double-blind, randomised, placebo-controlled trial, Lancet Neurol. 7 (2008) 779-786; DOI: 10.1016/ S1474-4422(08)70167-4.

76. P. A. Adlard, R. A. Cherny, D. I. Finkelstein, E. Gautier, E. Robb, M. Cortes, I. Volitakis, X. Liu, J. P. Smith, K. Perez, K. Laughton, Q.-X. Li, S. A. Charman, J. A. Nicolazzo, S. Wilkins, K. Deleva, T. Lynch, G. Kok, C. W. Ritchie, R. E. Tanzi, R. Cappai, C. L. Masters, K. J. Barnham and A. I. Bush, Rapid restoration of cognition in Alzheimer's transgenic mice with 8-hydroxy quinoline analogs is associated with decreased interstitial A $\beta$, Neuron 59 (2008) 43-55; DOI: 10.1016/j.neuron.2008.06.018. 


\title{
$S A \check{Z} E T A K$
}

\section{Kovinski ioni, Alzheimerova bolest i kelacijska terapija}

\author{
ANA BUDIMIR
}

Najnovija istraživanja na polju neurodegeneracije jasno pokazuju da kovinski ioni imaju značajnu ulogu u patogenezi Alzheimerove kao i drugih neurodegenerativnih bolesti. U skladu s ovim spoznajama upotreba kovinskih kelatora predstavlja zanimljiv i inovativan farmakološki pristup daljnjem istraživanju i mogućoj terapiji neurodegenerativnih stanja. U ovom radu ukratko je dan sažetak istraživanja upotrebe kovinskih kelatora $\mathrm{u}$ tretmanu Alzheimerove bolesti s posebnim osvrtom na istraživanja analoga 8-hidroksikinolina.

Ključne riječi: kovinski ioni, Alzheimerova bolest, neurodegeneracija, kovinski kelatori, kelacijska terapija

Sveučilište u Zagrebu, Farmaceutsko-biokemijski fakultet, Zagreb 